evidence which would show that they had actually seen the book to which they refer. We have gathered information about all Wingate's mathematical books which De Morgan did not examine. We shall state where copies can be found, so that the data given here can be verified by those who are near the libraries named. We take up Wingate's books, one after the other, and show that none contains the slide rule.

(1) "L'Usage de la Règle de Proportion," Paris, I624. De Morgan's assertion that this book describes nothing more than Gunter's scale ${ }^{1}$ is corroborated by P. M. N. Benoit, ${ }^{2}$ who examined copies in the Bibliotheque nationale and the Bibliotheque Mazarine in Paris. There is a copy in the Bodleian Library.

Wingate brought out in 1626 in London a translation under the title "Use of the Rule of Proportion." Later editions appeared in $1628,1645,1658$, and 1683 . De Morgan saw the 1645 edition, a copy of which is in the British Museum. Wingate died in 1656 .

(2) "Arithmétique logarithmique," Paris, 1626. De Morgan described this book. " He saw also the "Logarithmeticall Table," London, 1635, which is anonymous, but is attributed to Wingate.

(3) "Construction and Use of the Line of Proportion," London, 1628. Copy in the British Museum. The "line of proportion" here described is merely a mechanical table of logarithms. There are no sliding parts.

(4) "Of Naturall and Artificiall Arithmetique," London, 1630. Copy in the Bodleian Library. Describes only the instrument named in the preceding text. The first part of this book was enlarged by John Kersey the elder in 1650 under the new title "Arithmetique Made Easie." De Morgan saw the editions of 1673 and $17600^{5}$ The second part was re-edited by Wingate in 1652 . Copy in the British Museum. The instrument described here is still the "line of proportion."

(5) "Ludus Mathematicus," London, 1654, 1681. De Morgan ${ }^{B}$ inspected the first edition.

(6) "Use of the Gauge-rod," London, $165^{8}$ (second edition).

(7) "The Clarks Tutor for Arithmetick and Writing ... being the Remains of Edmund Wingate," London, i671. Copies of both books in the Bodleian Library. Neither contains an account of the slide rule.

\section{MASONRY ARCHES}

A MEMOIR dealing with a subject of great interest to the engineer has recently been issued as a Drapers' Company Research Memoir. ${ }^{1}$ It must be admitted that the ordinary treatment of the masonry arch is by no means satisfactory, and therefore any solution of the problem which would give more accurate and trustworthy results without involving excessive labour in the necessary calculations would be welcomed by every engineer who may in the course of his professional duties have to deal with the design and erection of masonry or brick arches.

After discussing the ideal arches for different load conditions, the authors show that for the fairly flat arches of modern practice designed to carry (I) a uniform load per foot run of the rib, or (2) a vertical load rising to a horizontal at a height $l^{2} / 8 r+r / 6$ above the central line at the crown, the elliptic arch is the proper design.

The rest of the memoir is devoted to an investigation of the extent of the applicability of the elliptic arch. It is shown that for the loads usual in masonry arches the elliptic arch is only closely approximate to the ideal if the ratio of rise to span be small, this latter condition involving large horizontal thrusts and great compressive stresses.

The authors then show that a close approximation to the arch the line of pressure of which coincides with its central line can be obtained with no great labour of calculation, and such an arch they term a pseudo-elliptic arch.

1 "Arithm. Bnoks," p. 42.

2 "La Règle à Calcul expliquee," p. vi. (Paris, 1853.)

3 " Penny Cyclop.,", Art. "Tables," p. 497. 4 "Loc. cit., p. 498.

5 "Arithm. Books," pp. 48, 73

6. Op. cit., p. 44

7 "On a Practical Theory of Elliptic and Pseudo-elliptic Arches, with Special Reference to the Ideal Masonry Arch." By Prof. Karl Pearson W. D. Reynolds, and W. F. Stanton. Pp. $23+6$ plates. Drapers' Company Research Memoirs, Technical Series, VI. (London: Dulau and Co., rgog.)
Price 4 s.

NO. 2096, VOL. 82]
The necessary equations to give the required solution are obtained, and an example is worked out in detail to show the application of the method and to prove that the labour of the necessary calculation is not a serious obstacle to the employment of this method. The memoir is illustrated by six plates reproduced from actual drawings.

The applied mathematics department of University College is to be congratulated on this valuable addition to the series of research memoirs dealing with difficult engineering problems for which Prof. Karl Pearson and his students have been responsible. $\quad$ T. H. B.

\section{UNIVERSITY AND EDUCATIONAL INTELLIGENCE:}

Graduates of the late Royal University of Ireland who desire to be registered as graduates of the Queen's University of Belfast, or enrolled as 'members of Convocation, should communicate as early as possible with the secretary of the latter University. The first meeting of Convocation must be held within the next four months.

WE learn from Science that, according to figures available in the office of the auditor, the University of Chicago holds investments representing permanent endowment that amount to $2,974,000 l$. In addition, its buildings and grounds devoted entirely to university use represent $1,783,540 l .{ }^{\circ}$; equipment, scientific apparatus, furniture, \&c., being put at $383,260 l$. additional. These figures do not include the funds destined for the erection of the Harper Memorial Library, estimated in round figures to cost $180,000 l$., nor the cost of the classical building, the construction of which is in contemplation, and on which about $50,000 l$. will be expended.

Dr. Charles Graham, at one time professor of chemistry at University College, London, and a prominent member of the Society of Chemical Industry, who died on November I3, has left the residue of his estate for medical research. The amount available will probably be $35,000 l$., and it is left to the Senate of the University of London to found a fund, to be known as the Charles Graham Medical Research Fund. The fund is to be applied in aid of any research carried on by a teacher or student of the school of advanced medical studies of the University College Hospital for the prevention, cure, or alleviation of human disease or suffering. If any student or teacher conducts a research which is considered of sufficient merit a gold medal of appropriate value is to be awarded to him. The committee of the school is also to pay to such teacher or student conducting the research an annual sum not exceeding $200 l$. per annum for two years, such person to be known as the "Charles Graham Student in Pathology."

THE Department of Agriculture and Technical Instruction for Ireland has issued a syllabus (Circular 70) of the examination which it proposes to hold in the princtples, methods, and history of education, with special reference to science teaching. The examination will be held in June of each year. The examination is provided for candidates seeking recognition of qualification to teach science. Among the subjects included in the syllabus are:-The general characteristics of the curriculum and methods of instruction in science as determined by the laws of general development; the correlation of science with other subjects of the curriculum. The methodology of instruction in science as determined by the laws of development of knowledge; the functions and relations of laboratory work and class-teaching. The critical study of the history of a special branch of science so far as it bears upon the teaching of the subject. The use of note-books and textbooks in science teaching; methods of recording and treating observational data. The construction and use of pictorial illustrations, diagrams, and models; the construction of apparatus. Laboratory organisation and management.

THE "Regulations for Secondary Schools" of the Board of Education lays it down that in all fee-charging secondary schools free places must be offered, under certain conditions, at the beginning of each school year to pupils entering from public elementary schools. The number of such places offered must ordinarily be 25 per cent. of the total number of pupils admitted to the school during the previous 